Jacob Emmanuel Mabe

\title{
Security Thought in Africa in the Context of Global Ethics
}

\begin{abstract}
:
There are few themes today that bear as much political significance as that of security. As a philosophical concept security is an ancient human ideal to which individuals as well as communities have constantly aspired. This paper focuses not only on thought about security issues in Africa in the context of global ethics but also on the rule of the new drums and bells, namely the modern informational media, for the diffusion of knowledge in Africa. Internet, mobile phone etc. are to be seen and accepted by Africans as an essential part of modern world culture.
\end{abstract}

\section{Agenda}

Introduction. 210

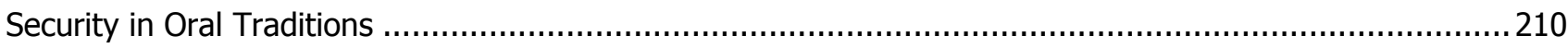

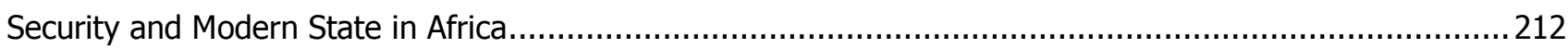

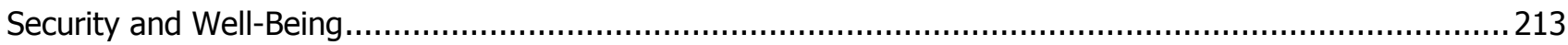

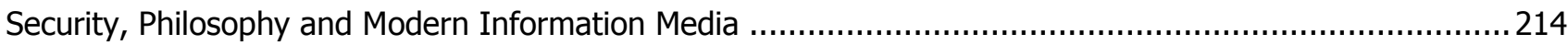

\section{Author:}

Dr. Dr. Jacob Emmanuel Mabe:

- Technische Universität Berlin, Institut für Philosophie, Wissenschaftstheorie, Technik- und Wissenschaftsgeschichte, Ernst-Reuter-Platz 7, 10587 Berlin, Germany

- +40-30-314-25633, $\square$ Jacobemabe@t-online.de, 묘 www.Jacobmabe.de

- Relevant publications:

- Die Kulturentwicklung des Menschen nach Jean-Jacques Rousseau in ihrem Bezug auf die gesellschaftlichen Entwicklungen in Afrika, Stuttgart: Verlag J.B. Metzler 1996, 243 p.

- Das Afrika-Lexikon. Ein Kontinent in 1000 Stichwörtern, Stuttgart and Wuppertal: Verlag J.B. Metzler and Peter Hammer Verlag 2001, 716 p. (Special Edition 2004).

- Das Kleine Afrika-Lexikon. Politik - Wirtschaft - Gesellschaft, Stuttgart: Verlag J.B. Metzler 2002 and Bonn: Bundeszentrale für politische Bildung 2004, 225 p.

- Mündliche und schriftliche Formen philosophischen Denkens in Afrika. Grundzüge einer Konvergenzphilosophie, Frankfurt am Main/Zürich/ New York/Paris: Peter Lang 2005, 508 p.

- Anton William Amo interkulturell gelesen, Nordhausen: Verlag Traugott Bautz 2007, 120 p. 


\section{Introduction}

Security is a political principle the primary function of which is to guarantee national and international peace. Thus, this concept cannot be viewed exclusively through its political or economic aspects, because it is a problem that encompasses all areas of life. Security is also an ancient human ideal to which individuals as well as communities have constantly aspired.

The politicisation of the question of security is indeed not new. In the time following September $11^{\text {th }}$ 2001's apocalyptic attack on New York, the metropolis of modern capitalism, debates about security have taken on an unforgettable global dimension.

As the immediate victim, the USA not only inspired worldwide compassion, but also experienced an indescribable solidarity. Indeed the USA exploited this sympathy to gain the commitment of all western countries under their aegis, as well as many other governments, in the fight against terrorism. Meanwhile most countries treated defence against terror as an urgent duty for their own stability and security as well as for that of the international community.

Although terrorism is a global concern, the African governments cannot grant it such a high priority, as the international fight against it works to their disadvantage. ${ }^{1}$ Apart from the fact that Africa has concerns of its own, security can only be an issue if people have serious worries and fears about their lives. In this light, security only becomes a truly global issue if there arises a threatening situation for the existence of humanity at large.

Whoever considers, for example, war, terrorism, AIDS, witchcraft, climate change, poverty, religious extremism, etc. as global concerns should at the same time search for universal concepts toward their solution. What is meant by 'universalism' is nothing other than a mode of thinking which is only realisable through a fusion of the awarenesses of multiple cultures. In the context of a universal awareness, the question arises whether approaches to security in Africa up until now can offer theoreti-

1 Njoh-Mouelle remarks: „Il faut distinguer entre les intérêts en afrique et les intérêts de I'Afrique." Ebenezer Njoh-Mouelle, 2006: Jalons I. L'Africanisme aujourd'hui, 2. Ed. (Yaounde: Editions Clé), p. 19. cal foundations for a world or global ethic for such intercultural debates as those over security.

This paper focuses on thought about security concerns in Africa by reviewing the perspectives of modern thinkers in the written records without ignoring the oral tradition, which is still highly respected in African philosophy. ${ }^{2}$

\section{Security in Oral Traditions}

Especially in oral traditions, they are peoples who believe that security can be satisfied less by material goods than by a spiritual energy that counters negative intrusions on human life. This energy, also called 'vital force', embodies all constantly active immaterial forces in human beings providing not only good health, a balanced nature, satisfaction and thus security, but also transmitting the inner confidence that one does not have to be afraid of anything.

There are people in Africa who believe in the existence of such forces, which can protect them from unnatural death and incurable diseases as well as from witchcraft and magical attacks, that can cause mental and physical suffering. ${ }^{3}$ They believe that these forces make them immune. Along with faith in the positive effect of vital force, there is an almost boundless dominance of the spiritual self over the

2 Cf. Jacob Emmanuel Mabe (Ed.), 2001: Das Afrika Lexikon. Ein Kontinent in 1000 Stichwörtern, [The Encyclopedia of Africa. A Continent in 1,000 Words] (Stuttgart: J.B. Metzler - Wuppertal: Peter Hammer); Jacob Emanuel Mabe 2005: Mündliche und schriftliche Formen philosophischen Denkens in Afrika. Grundzüge einer Konvergenzphilosophie [Oral and written forms of philosophical thinking in Africa. Groundwork of a Convergence Philosophy] (Frankfurt - Berne New York: Peter Lang); Paulin J. Hountondj (Ed) 1995: Les savoirs endogènes. Pistes pour une recherche (Paris: Karthala).

3 See Sophie B. Oluwole, 1992: Witchcraft, Reincarnation, and the God-Head - Issues in African Philosophy (Lagos: Excel Publishers); Meinrad Hebga, 1982: Sorcellerie et prière de délivrance: réflexion sur une expérience (Paris: Présence Africaine - Abidjan: INADES). 
possession of material goods (money, wealth, food, accommodation, clothes etc.).

This view of security relying primarily on oral traditions, has a large influence both on ethno-philosophy as well as on other scientific disciplines dealing with traditional myths and rules of life. As far as vitality is concerned, its effect is interpreted in the oral-traditional metaphysic as a transcendent moment, whereby the soul moves between the sensory and extrasensory sphere and between this and the next world. This association of vital force and security may appear mystical, but it must not be attributed to superstition; rather it has a rational basis.

Beyond its rationality, the concept of security proves that the feeling of need in traditional Africa was no simple projection of emotions on social and cultural life, but was rather connected with intellectual life. The ensuing ideas have an integrating function, merging the concept of security with the concept of one's own life process, ultimately creating the idea that the protection of the individual is synonymous with the protection of the community.

The rationality of the oral-traditional consciousness is self-explanatory in its differentiation between security as a need based solely on sensations such as fear, isolation, mourning, powerlessness and desperation, etc., and security as the necessity of thinking reasonably in order to preserve one's life. It is precisely the confrontation with the circumstances of a mundane existence which forces human beings with a talent for common sense to use their vital force (and not magic powers) as well as their extrasensory or transcendent ability. Reason thereby has the function of increasing the sensitivity of a human being in such a way that he senses his vital force and can use it accordingly.

The belief also exists, however, that if a person has low vital force, his intrinsic sensitivity may not be sufficient for either recognizing his vital force or finding compensatory forces to strengthen mental and physical efficiency. It may be that one can attain security-autarchy by rescinding or compensating for one's insufficiency in spiritual energy. There is unfortunately not a single oral-traditional teaching that rationally explains what vital force is and how one obtains it.

It would be correct to say that one can make the connection to the other world by exact knowledge of the laws of nature, which one acquires by the methods of initiation, inspiration and mediation. In the oral tradition one speaks of contact with immaterial essences, i.e. the ancestors, who allegedly determine the interrelation between the other world and this one. By so doing, the ancestors are regarded as intermediaries between the visible and the invisible world, between the living and dead. In all likelihood, memorial celebrations for the ancestors probably developed from the need to call for the assistance of the deceased.

Other peoples in Africa practice no ancestral cult but nevertheless regard their deceased relatives as companions of fate who are always present despite their invisibility, not only with them, but protecting them against any curse. Some who often visit fortunetellers, oracles, clairvoyants, and visionaries wish through them to re-establish an interrupted link with the ancestors. Carrying talismans, amulets, pieces of bark and other jewellery made out of gold, silver or diamonds is linked, however, to the intention of preventing the entrance of evil and thus achieving a life absent of suffering without the direct effect of vital force.

During ancestral memorial celebrations, which symbolize the meeting between deceased and living persons and which are still practised in many parts of Africa, the dead are called upon to be constantly present among their living descendants as well as to provide for their security. But the ancestral faith in Africa has been able to last mostly because of the general attitude of malaise toward all cultural and social areas having to do with modern trends.

Through modernization, egoism, power, greed for money, individualism, fame, luxury, personal prestige etc. have caused the decay of traditional customs and morals. From this moral erosion, two almost irreconcilable and antagonistic developments have resulted: on the one hand, a return of superstition at an explosive rate, and on the other hand, a rapid return of the struggle toward the spiritual. It is precisely this dominance of the spiritual which proves that not all Africans are victims of moral perversion, but rather that many have remained faithful to their ethical and metaphysical traditions. Indeed, spirituality indicates a nostalgic striving both for proximity to the ancestors and for harmony. Security for most Africans is reached only if people live in harmony with themselves as well as with their environment and with fellow men.

Among the spiritual inheritances of the oral tradition lie the rituals, the customs, as well as the living norms documented in the various languages, which for generations have been the basis for the metaphysical, ethical, cosmological, logical aesthetic 
thinking and behaviour of the African peoples. They are the most important indications of African spirituality and the fact that previous generations did not understand life as a random process but as a decision - a conscious act of free will. The oral-traditional inheritance may be based on unwritten theories; nonetheless it represents a substantial source without which a complete or adequate development of security consciousness is not possible in Africa.

Although the following security concepts have been passed on verbally from generation to generation, they still influence the thinking and behaviour of most African peoples:

- $\quad$ Old-age security by one's own child-bearing or by a close family bond and family loyalty;

- $\quad$ Protection of the home (mystical safety of house and property);

- $\quad$ Physical and personal protection (use of vitality for protection from unnatural death, voodoo, illnesses and suffering caused by witchcraft, accidents and other handicaps);

- $\quad$ Protection of the soil (spiritual safety of the soil or fields from infertility and possible harvest failures, which could be caused by others through envy, disfavour or jealousy;

- $\quad$ Food-security or security of food resources.

If these concepts are reminiscent of the intellectual achievements of generations that are now outdated, they nevertheless make it clear how people dealt with their existential fears in the past (fear of hunger, death, suffering, loneliness, etc.). This is because they could thereby also cultivate positive emotions (joy, peace, well-being, solidarity, love, compassion, etc.), in order to overwhelm negative emotions (mourning, rage, aggression, hate, egoism, envy, jealousy, etc.), which usually created uncertainty or insecurity.

In Africa's present societies most scholars no longer think only in terms of oral traditions. Rather they rely almost exclusively on philosophical methods and theories. Thus, they understand security as a term which can be interpreted as metaphysical, ethical, hermeneutical etc. But for the overwhelming majority of African sociologists, security is above all about protection from:

- political or religious prosecution,

- social inequality,

- racial and sexual discrimination,

- hunger and poverty,
- hate, envy and war.

\section{Security and Modern State in Africa}

The development of the contemporary security thought goes hand in hand with the developments of the natural sciences - from medicine through biotechnology and ecology up to energy technology which, with ever new findings, claim to help people to have a more contented life. African intellectual culture did achieve new weight as a result of scientific innovations, but did not however gain moral and cognitive quality.

For most political philosophers of Africa the term 'security' represents a principle underlying all national actions, which pursues the goal of promoting economic and political development. This has led to African states always associating their familial, social and economic policy with the protection of families and human rights, the safeguarding of the right to work, the protection of mothers', women's and children's rights by acknowledging their dignity, with consolidation of peace outwardly by the military and inwardly by the police, with social safeguards, with the guarantee of good health care etc. If one translates the traditional behaviour and rules of thought into the current reality, then one can observe that the attitudes of Africans in matters of security have changed somewhat less socially and culturally than economically and politically.

The fact that the post-colonial states have so far not succeeded in fulfilling the desires of their citizens for security can be explained by the following line of argument: it is undeniable that those in the West, with the use of economic, developmental and security policies, have for decades restricted the freedom of action of the elite African leadership. However, since the independence of their countries, the latter have also made the error of exercising their authority for power instead of developing it through the acceptance of the population. Unfortunately, even some young rulers have continued this wrong strategy by continuing to rely on measures of intimidation of the population by the judicial authorities, the police, and the military. They thereby hope to promote the adjustment of their fellow citizens to the requirements of modern democracy and development. And thus, they find themselves in a dilemma. On the one hand they want to take care of everything themselves, including the citizen's individual security. On the other hand they demand 
more self-initiative from their people, although they do not grant them any rights of liberty. In this way no durable positive effect has resulted from more than 40 years of synergy of state and development in the fight against the substantial number of infant deaths, malnutrition, insufficient medical treatment, low life-expectancy, etc.

Moreover, the failure of the old idea of authority with the associated expansion of the national power monopolies led to a troubling depoliticizing of the citizens. The displacement of the inhabitants has had many consequences, not the least of which being that the traditional authorities (sages, healers, fortune-tellers, etc.), which in the past embodied the familial and ethnical heritage and with whom people once sought protection, have almost lost their importance. But for some Africans the real problem of their countries lies primarily in their confidence in the State and the modernism of its political and university leadership elites, which for years have been destroying the oral along with all other cultural traditions in favour of modernization. An actual danger thereby exists in the neglect of verbal forms of predictions, foretelling, prophecy and sapience, which in the past served the organization and the co-operation of the community.

For Africa's contemporary state theoreticians security has a direct relation to dignity, liberty and wellbeing. Until 1960, colonial violence, oppression and exploitation stood at the centre of state-theoretical considerations. Aimé Césaire (*1913), Léopold Sédar Senghor (1906-2002), Kwame Nkruma (19091972), Frantz Fanon (1925-1961) et al, as well as the pan-African civil rights activists from America were unanimous in their opinion that the Africans' uncertainty is to be attributed to the degrading of cultures as well as the destabilization of the African societies caused by colonization. In their opinion, because Africa had been condemned to liberty, one had to undertake everything possible to end the coIonial subjugation and thus help Africans to restore their lost dignity.

From this assumption, Léopold Sédar Senghor and Aimé Césaire used poetry to try to communicate to Africans a new sense of self-value and security. Thereby the hopped to overcome the sense of shame and inferiority developed from racist discrimination which, in their opinion, made Africans feel insecure in their thoughts and acts. Frantz Fanon for his part recommended the use of force in order to counteract colonial oppression. It remains unclear however whether or not in so doing, he preferred military operations exclusively. In contrast to this, Amilcar Cabral (1924-1973) postulated the use of magic, witchcraft, gris-gris, voodoo, amulets, etc. in the fight for independence, in order to blind and weaken the attacking enemies.

Apart from his untiring commitment to African unity, Nkrumah with his Consciencism tried to develop a society of equality on the basis of socialism. With his Ujamaa doctrine, Julius Nyerere (1922-1984) strived towards a socialism based on a fair distribution of goods. Being firmly convinced of the fact that only labour could ensure individual and collective security and liberty, Nyerere pursued the goal of not only removing the gap between rich and poor but by using Tanzania as an example, he showed how one could assure the right to work for each citizen of the state. Up until the current day, Samir Amin (*1931) still struggles for the substitution of the existing metropolitan world market order, which promotes the pauperization of the African and South American countries as well as some parts of Asia, to a capitalism-free and safe world.

All states which have become independent since 1960 have let themselves be influenced directly or indirectly by totalitarian ideologies, which declare the solution of all security questions including 'humanitarian security' (the protection of children, civilians, the disabled, the elderly, land, property etc.) to be the exclusive task of the state. According to Fabien Eboussi Boulaga4, the fact that all political strategies have so far failed can only be attributed to the ethical retardation of Africa. Without founded ethical bases, neither politics nor its different ideologies can meet the challenges of modern society.

\section{Security and Well-Being}

This paper limits itself to Ebenezer Njoh-Mouelle, probably the only modern professionnal philosopher who has dealt intensively with the term 'security'. The point of departure from which Njoh develops his concept of security lies beyond philosophical considerations that treat security as a biological instinct of self preservation. In his book: De la médiocrité à

\footnotetext{
${ }^{4}$ See F. Eboussi Boulaga (1977): La crise du muntu. Authenticité africaine et philosophie, (Paris: Présence africaine).
} 
l'excellence ${ }^{5}$ he draws a close correlation between security and well-being.

Njoh-Mouelle differentiated between two forms of security: security as a life-preservation and security as an accomplishment for the preservation of humanity. In the first case, security concerns the preservation and safe-guarding of earned life. In the second case it aims at the realization of humanity in mankind, i.e., in well-being for all. What then is well-being exactly? Njoh-Mouelle defines it as a condition of the healthy and balanced body and spirit which mindfully excludes desires for individual security based on luxury and abundance - desires for which human beings today strive worldwide.

Moreover, according to Njoh-Mouelle, well-being is synonymous with qualitative and objective security. Thus one should not confuse it with (non-qualitative conditions such as) greed or other quantifiable (but non-objective) insatiable material security needs. Objective security, which is at the same time wellbeing, goes beyond the material fortune of human beings to include physical, emotional and spiritual contentment through healthy living, healthy food and a healthy way of life. According to NjohMouelle, the realization of well-being presupposes above all the use of intellectual means (by education and instruction), which helps people to become creative beings, humans who can secure their biological and spiritual existence through their own strength. This means that the striving for well-being accompanies the spiritual emancipation of human beings towards liberty and bliss.

If security needs are an instinct of self-preservation, then human beings who follow the law of nature create artificial means which can serve their preservation and the perpetuation of human kind. In opposition to this, Njoh-Mouelle believes that human beings, due to their ability to reason, are condemned to invent technical and other artificial means yet be unable to use them in such a way as to stand in contradiction to nature or to run contrary to their existence.

In this regard, security makes a demand for objectivity only if the human lifestyle corresponds to a large extent to the natural order as well as to social

5 E. Njoh-Mouelle (1988): De la médiocrité à l'excellence. Essai sur la signification humaine du développement. Suivi de: développer la richesse humaine, 2nd. ed. (Yaounde:Editions Mont Cameroun). harmony. Self-preservation thus includes not only life-preservation and self-realization, but also the preservation of the species and the achievement of the goals of mankind. Njoh-Mouelle therefore pleads that well-being, both as an ideal condition in life and as the goal of security, should be attained in dignity.

\section{Security, Philosophy and Modern Information Media}

This article concerns itself entirely with discerning the meaning of modern information media for the diffusion of knowledge in Africa. Since the dawn of man, humanity has constantly created instruments for communication, or the mutual exchange of information, knowledge, ideas and experiences. For this reason, homo communicans (the communicative being) is much older than the classical drummers of Africa and the bells of Europe, which were limited to closed communities and circumscribed areas.

The internet, the mobile phone, etc., are these drums and bells but with an infinitely higher audibility, which can reach people who are scattered around the world. According to the body of critical literature these new media are not extraneous, but are to be seen as an essential part of modern world culture, in that they shape thought and behaviour, in short the life of humanity.

As technologies, modern media are on the rise worldwide. Africa does not however need a kind of media that is oriented primarily toward economic profit, but one that is built upon an open communication among all strata of the population. They must provide for the construction of democratic and civil-societal structures in which they make the political decision-making and development processes public, especially those which have large significance for the security of the citizens. Despite the increasing drive for commercialisation, it is important to prevent new media from completely destroying spiritual life in Africa, the value of which has already suffered in the modern global community.

Indeed the modernisation of communication is indispensable in contributing to the body of literate and highly educated Africans. The latter have security needs (such as money, paid work, pension, education etc.), which cannot be satisfied by orally passed-down thought. Furthermore, the speed of globalisation is creating a radical transformation of the African community, as well as a significant reorientation of the institution of education toward communications systems. Whether this develop- 
ment is associated with the destruction of native languages and ethnic cultures cannot be predicted at this stage.

Many passed-down ways of living and thinking can only be salvaged, however, if philosophers especially stop treating new media, as they have in the past, as a contrivance that damages culture, but understand it instead as a useful art which can and should facilitate debates, even between scattered thinkers over great distances, about metaphysical, ontological, ethical, moral, logical, epistemological, hermeneutical, and historical questions, etc. For the first time in the history of humanity Africans, Europeans, Asians, Americans etc. are in the position to discuss commonly and to discourse about political and religious misjudgements as well as economic and social misdirections.

The new drums and bells should therefore be used sensibly and consequentially for inter-African debates in which philosophers can use all available speed in broadening their concepts and discussing them among one another before they offer their ideas to universal criticism. In this light, among the deliberations about global considerations can also be counted the readiness of philosophers to contribute serious thinking about their association with modern media. Philosophy is now required to formulate a new ethics which can see to it that the media technology generated by humanity itself does not conflict with human security needs.

\section{References}

Bidima, Jean-Godefroy, 1995: La philosophie négroafricaine (Paris: Presse Universitaires de France).

Hebga, Meinrad, 1998: La rationalité d'un discours africain sur les phénomènes paranormaux ( $\mathrm{Pa}$ ris: L'Harmattan).

Hountondji, Paulin J. (Ed.), 1995: Les savoirs endogènes. Pistes pour une recherche (Paris: Karthala).

Mabe, Jacob Emmanuel, 1996: Die Kulturentwicklung des Menschen nach Jean-Jacques Rousseau in ihrem Bezug auf die gesellschaftlichen Entwicklungen in Afrika (Stuttgart: J.B. Metzler)

Mabe, Jacob Emmanuel (Ed.), 2001: Das Afrika Lexikon. Ein Kontinent in 1000 Stichwörtern [The Encyclopedia of Africa. A Continent in 1,000 Words] (Stuttgart: J.B. Metzler - Wuppertal: Peter Hammer).

Mabe, Jacob Emmanuel, 2005: Mündliche und schriftliche Formen philosophischen Denkens in
Afrika. Grundzüge einer Konvergenzphilosophie [Oral and Written Forms of Philosophical Thinking in Africa. Groundwork of a Convergence Philosophy] (Frankfurt - Berne - New York: Peter Lang).

Njoh-Mouelle, Ebenezer, ${ }^{2} 1988$ : De la médiocrité à I'excellence. Essai sur la signification humaine du développement. Suivi de: développer la richesse humaine (Yaounde: Editions Mont Cameroun).

Njoh-Mouelle, Ebenezer, 22006: Jalons II L'africanisme aujourd'hui. (Yaounde: Editions $C L E)$

Odera Oruka, Henry, 1997: Practical Philosophy: In Search of an Ethical Minimum (Nairobi: East African Educational).

Oluwole, Sophie B., 1992: Witchcraft, Reincarnation, and the God-Head - Issues in African Philosophy (Lagos: Excel Publishers).

Tempels, P., 1959: Bantu Philosophy (Paris: Précence 